\title{
Peertechz
}

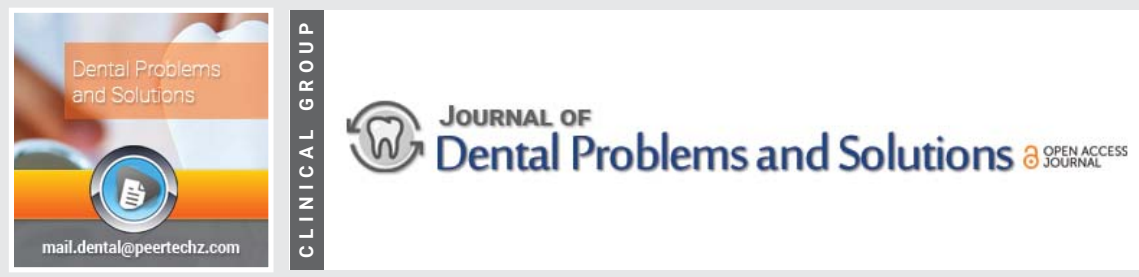

SSN: $2394-8418$

DOl: https://doi.org/10.17352/jdps

Received: 01 February, 2021

Accepted: 16 February, 2021

Case Report

\section{Endodontic treatment of} maxillary incisor with dens invaginatus and dens exvaginatus: Case report

\section{Insoon Chang*}

Section of Endodontics, Division of Constitutive and Regenerative Sciences, Division of Advanced Published: 17 February, 2021

*Corresponding author: Insoon Chang, DDS, MS, PhD, Lecturer, Section of Endodontics, Division of Constitutive and Regenerative Sciences, Division of Advanced Prosthodontics, UCLA School of Dentistry, Los Angeles, California, USA, Tel: 310-825-4348;

E-mail:ichang@dentistry.ucla.edu

Keywords: Dens invaginatus; Dens-in-dente; Root canal treatment; Dental anomaly

https://www.peertechzpublications.com

Prosthodontics, UCLA School of Dentistry, Los Angeles, California, USA

\begin{abstract}
Dens Invaginatus (DI) and talon cusp are rare dental malformations involving complicated clinical and anatomical features and pose many approaches to managing the case. In this case, lingual caries led to pulp necrosis on tooth \#10 with two Type II Oehler's DI chambers with talon cusp. Nonsurgical endodontic treatment was achieved using modern endodontic techniques and material. On the other hand, tooth \#7 with Type I Oehler's DI with lingual caries was not associated with pulp pathosis and indicated with a preventative treatment approach.
\end{abstract}

\section{Introduction}

Dens Invaginatus (DI), also known as dens in dente, is a rare dental malformation involving an infolding of the dental papilla before calcification of dentine during tooth development [1]. The definitive etiology of DI remains unclear, but genetic and environmental factors may contribute to this malformation process [2]. DI affects $0.3 \%$ to $10 \%$ of the population, and the most commonly affected teeth are the permanent lateral incisors, followed by maxillary central incisors, and premolar and canine teeth [2]. According to Oehler's classification system, the anatomy of DI is complex and classified into three categories [3]. Understanding this classification will help decide the appropriate treatment options for each different type of DI lesion.

1. Type I - invagination occurs within the confines of the crown and does not extend beyond Cemento-Enamel Junction (CEJ).

2. Type II - invagination invades root but does not have separate foramen.

3. Type III - invagination penetrates the root and exits as distinct apical foramen and does not communicate with the pulp.
The presence of invagination is clinically significant because it portrays an increased risk of caries, pulpal pathosis, and periodontal inflammation since microorganisms can stagnate and propagate within infolds [4]. Early detection and diagnosis are essential as prophylactic treatment may prevent an advanced treatment such as root canal therapy. The nature of the altered and complex anatomy of DI can often complicate the endodontic management of the tooth [2]. Talon cusp is dens evaginatus occurring at the lingual surface of anterior teeth [5]. Although isolated cases of talon cusp and DI are often observed in permanent maxillary lateral incisors, the frequency of these two anomalies' coexistence in a single tooth remains rare, and only a few cases have been previously reported $[5,6]$. This report describes a case of talons cusp and 2-chamber Type II DI lesions associated with the maxillary lateral incisor.

\section{Case report}

A 14-year-old female with noncontributory medical history was referred by her general dentist. At the time of the referral, tooth \#10 was asymptomatic and negative to cold test with deep lingual caries. The referring dentist observed tooth \#10 has talon cusp, unusual radiographic presentation, and suspected pulp exposure might be inevitable during the caries control. Thus, tooth \#10 was referred for evaluation and treatment. During the clinical examination, the maxillary left (tooth \#7) 
and right (tooth \#10) lateral incisors were both observed with DI and caries on the lingual side (Figure 1).

A radiographic examination revealed that tooth \#7 has a radiopaque projection entering the root canal, lined by enamel not extending beyond the CEJ, and a complete root development without periapical radiolucency (PARL). Tooth \#7 was asymptomatic and normally responded to a pulp sensitivity test with no palpation or percussion pain. Tooth \#7 was diagnosed with Type I Oehler's DI with a normal pulp and normal apical tissue. Tooth \#7 will be monitored and was referred back to the general dentist for the caries control and composite restoration.

A periapical radiograph and Cone Beam Computed Tomography (CBCT) imaging of tooth \#10 (Figure 2) showed two radiopaque projections entering the root canal, lined by enamel extending beyond the CEJ, and a complete root development without PARL. The CBCT imaging also revealed that the DI entrance is located at the junction between the lingual wall and talon's cusp meets, and the mesial DI chamber communicates with the main central canal. Tooth \#10 was asymptomatic and was non-responsive to the pulp sensitivity test with no palpation or percussion pain. Tooth \#10 was diagnosed with necrotic pulp and normal apical tissue with two chambers of Type II Oehler's DI, and nonsurgical root canal therapy was indicated (Figure 3). Tooth \#10 was sealed with a composite restoration after endodontic treatment was completed (Figure 4).

\section{Procedure}

\section{Appointment Day 1}

1. The consent form was understood and signed by the patient's mother.

2. The estimated length and depth of two DI chambers were measured on CBCT imaging.
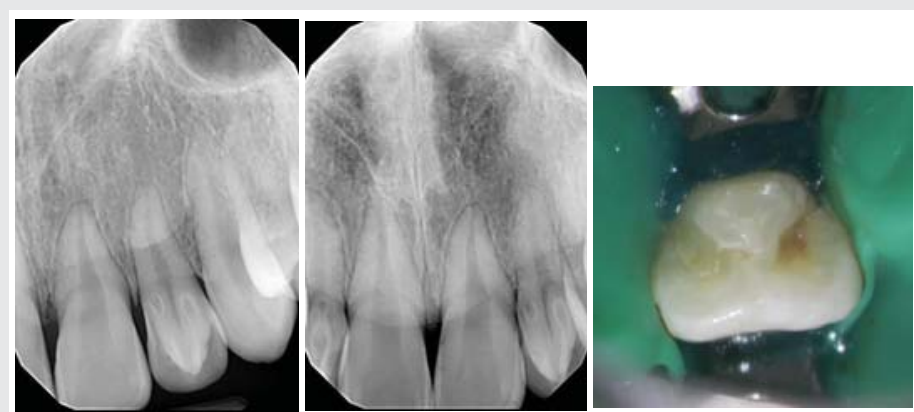

Figure 1: Pre-operative periapical radiographs and crown morphology (Tooth \#10).
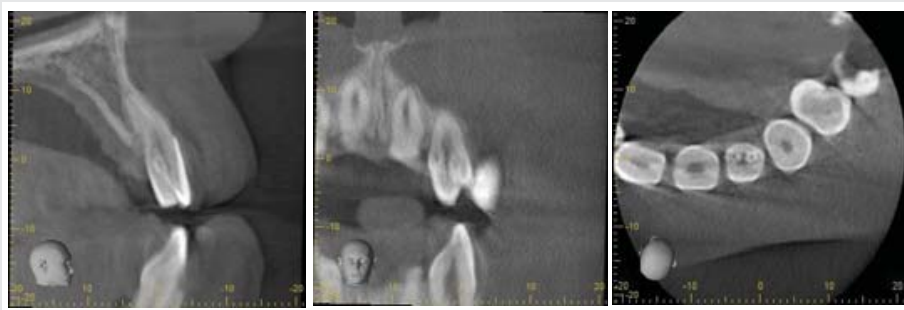

Figure 2: СBCT imaging of tooth \#10.

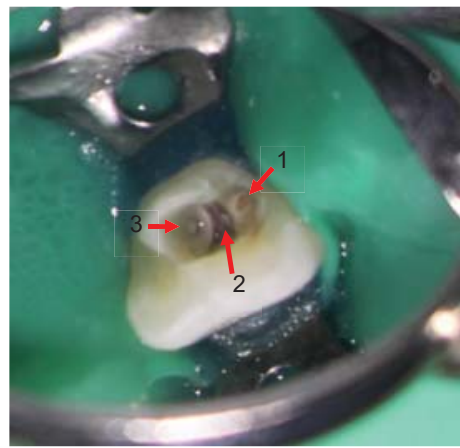

Figure 3: Access prep (1: mesial chamber, 2: central main canal, 3: distal chamber).

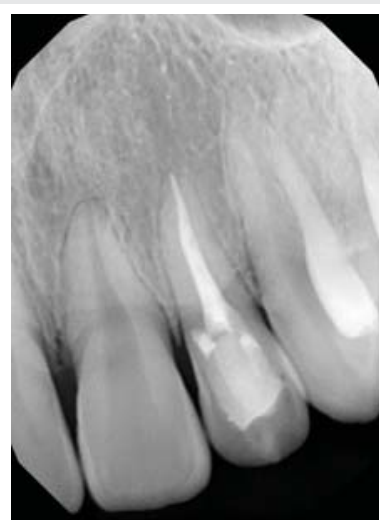

Figure 4: Post-operative radiograph.

3. Tooth \#10 was anesthetized and isolated with a dental dam and an anterior clamp.

4. Access was done and refined with \#2 and \#4 surgical length carbide burs and endo Z-bur. Two DI chambers and one central canal were identified using the microscope.

5. Cleaning and debridement were done using hand and rotary files and copious irrigation with 5.25\% sodium hypochlorite and $17 \%$ EDTA. Verified patency and working length with electronic apex locator, radiographs, and paper points.

6. Canals and chambers were dried, and calcium hydroxide was placed as an intracanal medicament. Tooth \#10 was temporized, and occlusion was checked in all exclusion.

\section{Appointment Day 2}

1. The patient presented to the clinic asymptomatic after one week from the first appointment.

2. Tooth \#10 was anesthetized and isolated with a dental dam.

3. Re-verified patency and working length, and irrigation were done with $5.25 \%$ sodium hypochlorite and $17 \%$ EDTA. Master cone fit was established and verified with radiographs.

4. The main central canal was obturated with warm 
vertical compaction using gutta-percha and $\mathrm{BC}$ sealer. The two DI chambers were empty obturated with BC putty and BC sealer.

5. The pulp chamber was cleaned. Etched, primed, and bonded with A2 flowable composite. Occlusion was checked in all excursions and polished the composite.

\section{Discussion}

Talon cusp and DI are uncommon dental anomalies that may affect the teeth' internal and external anatomy. However, the concomitant occurrence of dens evaginatus and DI on the same tooth is infrequent, and only a few cases have been previously reported for the permanent maxillary lateral incisors $[5,6]$. Talon cusp is dens evaginatus featuring a cusp-like cingulum projection on the lingual surface of an anterior tooth and has been reported to occur from $1-8 \%$ of the population $[6,7]$. DI is the result of malformation during tooth development resulting in an invagination of enamel into dentine. Comprehensive studies have been done and found that teeth affected with DI are predisposed to an increased risk of developing pulpal pathosis $[2,4,8]$. The invagination may provide a space to harbor microorganisms and promote caries development and bacterial infection into the pulpal space. Further, it can also occur without evidence of caries or a history of trauma [9]. Thus, early diagnosis of DI is crucial, and securing the opening of the invagination with a composite restoration can provide effective prevention of complications $[1,10]$.

The DI lesion can be diagnosed based on clinical and radiographic findings. If the DI entrance cannot be located and no signs of necrosis or pulpal pathosis are inevident, the tooth with DI lesion may be monitored without the treatment rendered [1-3]. In this case, tooth \#7 was diagnosed with normal pulp and normal apical tissue despite its features of surface caries and Type I DI. Thus, tooth \#7 was indicated with a preventative treatment plan to monitor and place composite restoration after caries control. On the other hand, if signs of necrosis or pulpal pathosis are evident, the tooth with DI lesion may be indicated for an endodontic treatment or other treatment options based on the types of DI lesion presented. In this case, tooth \#10 was diagnosed with necrotic pulp and normal apical tissue with deep caries near the pulp. Thus, tooth \#10 was indicated with a therapeutic treatment plan to perform nonsurgical root canal therapy, caries control, and composite restoration.

Rendering root canal treatment may present several complications due to the abnormal anatomy of the root canal system. The clinical presentation of DI can be a significant variation, and locating the entrance to the invagination could be challenging [11]. Furthermore, a standard parallel view of periapical radiographs may or may not reveal the presence and the complex three-dimensional anatomy of DI lesion. Thus, additional angulated radiographic imaging may need to be taken when a DI lesion is suspected. In this case report, high magnification and illumination provided by a microscope (Global surgical microscopes) helped identify the entrance to the DI lesion on tooth \#10. Moreover, CBCT imaging helped identify DI entrance and understand the complex three-dimensional anatomy of DI (revealing the actual size, extent, and position) in tooth \#10 prior to the access. CBCT is complementary radiographic imaging in diagnosing and managing DI with high resolution and accuracy [3,12]. A routine application of CBCT in endodontics is controversial due to the higher radiation dosage than two-dimensional radiographs. However, the application of СВCT to understand a complicated root canal system was essential in this case because a tooth had more than one Type II invagination.

The bioceramic putty (Endosequence Root Repair Material, Brasseler) was used as orthograde filling material to fill the two chambers of dens invaginatus. This material comes as a ready-mix paste offering ease of manipulation and has been reported to show similar or better results than Mineral Trioxide Aggregate (MTA) and minimized tooth discoloration [13].

\section{Conclusion}

Early diagnosis and prevention are essential to prevent complications in dens invaginatus cases. Because of pulpal necrosis, a nonsurgical endodontic therapy was indicated in this case. The use of microscope, СВCT, and bioceramic materials greatly enhanced diagnosis and the treatment procedure.

\section{References}

1. Hulsmann M (1997) Dens invaginatus: aetiology, classification, prevalence, diagnosis, and treatment considerations. Int Endod J 30: 79-90. Link: https://bit.ly/37kQWPT

2. Gallacher A, Ali R, Bhakta S (2016) Dens invaginatus: diagnosis and management strategies. Br Dent J 221: 383-387. Link: https://bit.ly/3pqeQj9

3. Zhu J, Wang X, Fang Y, Von de Hoff JW, Meng L (2017) An update on the diagnosis and treatment of dens invaginatus. Aust Dent J 62: 261-275. Link: https://bit.ly/3s14aca

4. Alani A, Bishop K (2008) Dens invaginatus. Part 1: classification, prevalence and aetiology. Int Endod J 41: 1123-1136. Link: https://bit.ly/3u30FEg

5. Mupparapu M, Singer SR, Goodchild JH (2008) Dens evaginatus and dens invaginatus in a maxillary lateral incisor: Report of a rare occurrence and review of literature. Aust Dent J 49: 201-203. Link: https://bit.ly/37gazbS

6. Lwin H, Kyaw P, Thu S (2017) Coexistence of true talon cusp and double dens invaginatus in a single tooth: a rare care report and review of the literature. Clin Case Rep 5: 2017-2021. Link: https://bit.ly/2LSMobN

7. Hattab FN, Yassin OM, Al Nimri KS (1996) Talon cusp in permanent dentition associated with other dental anomalies: review of literature and reports of seven cases. ASDC J Dent Child 63: 368-376. Link: https://bit.ly/2ZhCyn7

8. Nagaveni NB, Sidhant P, Anitha P, Poornima P (2015) An Overview of Dens Invaginatus with Report of 2 Cases. Journal of Clinical \& Experimental Pathology 5: 238. Link: https://bit.ly/3aouUxn

9. Seow WK (2003) Diagnosis and management of unusual dental abscesses in children. Aust Dent J 48: 156-168. Link: https://bit.ly/3bp4kUr

10. Rotstein I, Stabholz A, Heling I, Friedman S (1987) Clinical considerations in the treatment of dens invaginatus. Endod Dent Traumatol 3: 249-254. Link: https://bit.ly/2Zkfior

11. Bishop K, Alani A (2008) Dens invaginatus. Part 2: clinical, radiographic features and management options. Int Endod J 41: 1137-1154. Link: https://bit.ly/3jZoBnd 
12. Ball RL, Barbizam JV, Cohenca N (2013) Intraoperative endodontic applications of cone-beam computed tomography. J Endod 39: 548-557. Link: https://bit.ly/3jQpheH
13. Parirokh M, Torabinejad M, Dummer PMH (2018) Mineral trioxide aggregate and other bioactive endodontic cements: an updated overview - part I: vital pulp therapy. Int Endod J 51: 177-205. Link: https://bit.ly/3aq0fA2

\section{Discover a bigger Impact and Visibility of your article publication with Peertechz Publications}

\section{Highlights}

* Signatory publisher of ORCID

* Signatory Publisher of DORA (San Francisco Declaration on Research Assessment)

* Articles archived in worlds' renowned service providers such as Portico, CNKI, AGRIS, TDNet, Base (Bielefeld University Library), CrossRef, Scilit, J-Gate etc.

* Journals indexed in ICMJE, SHERPA/ROMEO, Google Scholar etc.

* OAI-PMH (Open Archives Initiative Protocol for Metadata Harvesting)

* Dedicated Editorial Board for every journal

* Accurate and rapid peer-review process

* Increased citations of published articles through promotions

* Reduced timeline for article publication

Submit your articles and experience a new surge in publication services (https://www.peertechz.com/submission).

Peertechz journals wishes everlasting success in your every endeavours.

Copyright: ๑ 2021 Chang I. This is an open-access article distributed under the terms of the Creative Commons Attribution License, which permits unrestricted use, distribution, and reproduction in any medium, provided the original author and source are credited. 